\title{
Synthesis and optical properties of $\mathrm{SiO}_{2}-\mathrm{Al}_{2} \mathrm{O}_{3}-\mathrm{MgO}-\mathrm{K}_{2} \mathrm{CO}_{3}-\mathrm{CaO}-\mathrm{MgF}_{2}-\mathrm{La}_{2} \mathrm{O}_{3}$ glasses
}

\author{
C R GAUTAM ${ }^{\#}$ \\ Advanced Glass and Glass Ceramic Research Laboratory, Department of Physics, University of Lucknow, \\ Lucknow 226007, India \\ \#Present address: Department of Materials Science and Nano Engineering, Rice University, P.O. Box 1892, \\ Houston, Texas 77005, USA
}

MS received 19 January 2015; accepted 1 December 2015

\begin{abstract}
A series of five glass compositions were prepared by using the conventional melt quenching technique in the system $\mathrm{SiO}_{2}-\mathrm{Al}_{2} \mathrm{O}_{3}-\mathrm{MgO}-\mathrm{K}_{2} \mathrm{CO}_{3}-\mathrm{CaO}-\mathrm{MgF}_{2}-\mathrm{La}_{2} \mathrm{O}_{3}$ with different contents of $\mathrm{SiO}_{2}, \mathrm{MgO}_{2} \mathrm{~K}_{2} \mathrm{CO}_{3}, \mathrm{MgF}_{2}$ and $\mathrm{La}_{2} \mathrm{O}_{3}$. The effects on the optical and physical properties of these glasses due to the addition of $\mathrm{La}_{2} \mathrm{O}_{3}$ as well as variation of the various oxides have been investigated. $\mathrm{X}$-ray diffraction analysis is used to confirm the amorphous nature of the prepared glasses. Structures of glasses were studied by using UV-Vis and Fourier transforms infrared spectroscopy. The drilling test was also performed on their glass ceramic samples to confirm the machinability.
\end{abstract}

Keywords. Glasses; XRD; FT-IR; UV-Vis spectroscopy; machinability.

\section{Introduction}

The fundamental building block is $\mathrm{SiO}_{4}$ tetrahedral unit, and in pure $\mathrm{SiO}_{2}$, all the oxygens are shared between two tetrahedra forming a fully polymerized network. Alkali or alkaline earth cations act as network modifiers, breaking bridging oxygen bonds to form non-bridging oxygens (NBOs) and residing in sites interstitial to the tetrahedral network in the vicinity of the negatively charged NBOs [1]. In 1970, Beal et al [2] reported machinable glass-ceramics containing phlogopite from the $\mathrm{SiO}_{2}-\mathrm{B}_{2} \mathrm{O}_{3}-\mathrm{MgO}-\mathrm{Al}_{2} \mathrm{O}_{3}-\mathrm{K}_{2} \mathrm{O}-\mathrm{F}$ glass system. Grossman [3] obtained tetrasilicic-mica glass-ceramics from the $\mathrm{K}_{2} \mathrm{O}-\mathrm{MgF}_{2}-\mathrm{MgO}-\mathrm{SiO}_{2}$ glass system. The structure of phlogopite is composed of a two-dimensional network of corner-shared $\left[\mathrm{SiO}_{4}\right]^{-}$and $\left[\mathrm{AlO}_{4}\right]^{-}$tetrahedra, forming an hexagonal ring. A layer of $\mathrm{Mg}^{2+}$ ions in octahedral coordination is located between two tetrahedral layers [4]. The triple layers are connected to each other by relatively large alkali ions, e.g., $\mathrm{K}^{+}$or $\mathrm{Na}^{+}$. Few systematic studies may be found on the influence of glass compositions on the formation of fluorphlogopite crystal phase [5]. $\mathrm{Mg}^{2+}$ is an important component of the mica structure, so $\mathrm{MgO}$ content affect the glass structure and the formation or shape of mica crystals [6]. Glass properties may be explained on the basis of network connectivity (NC), which is the number of bridging oxygen atoms (BO) per network forming element [7]. Thus, pure silica glass has an $\mathrm{NC}$ of 4 while a glass structure consisting of linear $\left[\mathrm{SiO}_{3}\right]_{n}^{2 n-}$ chains has an $\mathrm{NC}$ of 2 . NC can be used to predict glass surface reactivity, solubility or the likelihood of undergoing glass-in-glass phase separation and bioactivity [8]

gautam_ceramic@yahoo.com
Recently, a lot of work has been reported on the doping of different concentrations of $\mathrm{La}_{2} \mathrm{O}_{3}$ for $(\mathrm{Pb}, \mathrm{Sr}) \mathrm{TiO}_{3} /$ $(\mathrm{Ba}, \mathrm{Sr}) \mathrm{TiO}_{3}$ borosilicate glasses to act as network modifiers as well as nucleating agents [9-11]. Ceramic base materials are not suitable for some applications because of their brittle properties with respect to mechanical effects, such as cutting and drilling [12]. However, some modifications in chemical composition and production methods can provide better mechanical behaviour. One of the important materials that can be used to improve the machinability of ceramics is mica-based glass ceramics. Mica-based glass ceramics are used as high quality electrical insulators and exhibit high resistance to thermal shock and good machinability [13]. Mica-based glass ceramics based on the $\mathrm{SiO}_{2}-\mathrm{MgO}-\mathrm{MgF}_{2}-\mathrm{K}_{2} \mathrm{O}$ system are commercially produced and exhibit unique properties, such as remarkable cleavage, flexibility and elasticity, enabling excellent machinability [14]. Commercial mica-based glass ceramics are primarily of the fluorophlogopite type [15]. The glass ceramic derived from this investigated glass $\mathrm{SiO}_{2}-\mathrm{Al}_{2} \mathrm{O}_{3}-\mathrm{MgO}-\mathrm{K}_{2} \mathrm{CO}_{3}-$ $\mathrm{CaO}-\mathrm{MgF}_{2}-\mathrm{La}_{2} \mathrm{O}_{3}$ system are technologically very useful for machinable glass ceramics which have very important device applications such as crown, artificial bone, etc. More recently, a nominal composition of $\mathrm{SiO}_{2} 40 \%, \mathrm{Al}_{2} \mathrm{O}_{3} 12 \%$, $\mathrm{MgO} 10 \%, \mathrm{MgF}_{2} 24 \%, \mathrm{CaO} 5 \%, \mathrm{~K}_{2} \mathrm{O} 1 \%$ and $\mathrm{ZrO}_{2} 8 \%$ in weight ratio has been reported for dental CAD/CAM system [16].

In this research paper, our aim is to explore the structural networking between different glasses as formed and compositional effect due to variation of $\mathrm{La}_{2} \mathrm{O}_{3}$ on optical properties of the glass system $\mathrm{SiO}_{2}-\mathrm{Al}_{2} \mathrm{O}_{3}-\mathrm{MgO}-\mathrm{K}_{2} \mathrm{CO}_{3}-\mathrm{CaO}-$ $\mathrm{MgF}_{2}-\mathrm{La}_{2} \mathrm{O}_{3}$, because such type of results are not reported 
so far. The optical characterizations give the valuable information about the formation of bonding network between different oxide groups and crystallization. Hence, their glass ceramic can be easily machined for different device applications.

\section{Experimental}

\subsection{Glass sample preparation}

Five different glass compositions according to table 1 in the $\mathrm{SiO}_{2}-\mathrm{Al}_{2} \mathrm{O}_{3}-\mathrm{MgO}-\mathrm{K}_{2} \mathrm{CO}_{3}-\mathrm{CaO}-\mathrm{MgF}_{2}-\mathrm{La}_{2} \mathrm{O}_{3}$ glass system has been synthesized from high purity $(\geq 99 \%)$ raw materials: $\mathrm{SiO}_{2}, \mathrm{Al}_{2} \mathrm{O}_{3}, \mathrm{MgO}, \mathrm{K}_{2} \mathrm{CO}_{3}, \mathrm{CaO}, \mathrm{MgF}_{2}$ and $\mathrm{La}_{2} \mathrm{O}_{3}$. Appropriate amounts of chemicals were weighed by using a digital balance with an accuracy of $0.0001 \mathrm{~g}$. The weighed chemicals were thoroughly mixed in an agate mortar and pestle in acetone media until they were dried. The dried powders were melted in high pure alumina crucible at $1350-1450^{\circ} \mathrm{C}$ for $1 \mathrm{~h}$ until a bubbled free liquid was formed using electric furnace. The glass melt has been cast onto an aluminium block and quickly transferred into a preheated muffle furnace for annealing at $475^{\circ} \mathrm{C}$ for $3 \mathrm{~h}$ to avoid breaking of the glass samples through residual internal strain and then furnace cooled to room temperature. The prepared glass block was cut into small pieces for further characterizations.

\section{$2.2 \quad X$-ray diffraction}

Glass samples have been grinded with the help of mortar pestle to obtain fine powder. X-ray diffraction (XRD) data of powdered glass samples was recorded by a Rigaku Miniflex-II X-ray diffractometer using $\mathrm{CuK} \alpha$ radiation with step size of $0.02^{\circ}$ over the $2 \theta$ range of $10-80^{\circ}$.

\subsection{Density measurements}

Density of the glass samples depend upon the variation of $\mathrm{La}_{2} \mathrm{O}_{3}$ as well as on compositional changes. Therefore, the density of the prepared glass samples has been calculated by using Archimedes Principle [17]. Distilled water was used as the liquid medium. The densities of these glass samples are listed in table 1. The following formula was used for determination of density of the glass samples.

$$
\text { Density }=\frac{\left(W_{2}-W_{1}\right)}{\left(W_{4}-W_{1}\right)-\left(W_{3}-W_{2}\right)},
$$

where $W_{1}$ is the weight of empty specific gravity bottle (in grams); $W_{2}$ the weight of specific gravity bottle with sample (in grams); $W_{3}$ the weight of specific gravity of bottle with sample and distilled water (in grams); $W_{4}$ the weight of specific gravity bottle with distilled water (in grams). Density of distilled water is $1.0 \mathrm{~g} \mathrm{~cm}^{-3}$.

\subsection{Fourier transform infrared spectroscopy}

Fourier transform infrared absorption spectra of the annealed glasses were obtained at room temperature in the wavenumber range of $4000-400 \mathrm{~cm}^{-1}$ using a Fourier transform infrared spectrometer ((FT-IR), BX-II, Perkin Elemer). The samples were grinded into fine powder $(<180 \mu \mathrm{m})$ and then mixed with $\mathrm{KBr}$ powder in the ratio of 1:9 precisely. Subsequently, the mixtures were uniaxially pressed to form clear homogeneous discs. The FT-IR measurements were carried out immediately after preparing the discs to avoid moisture absorption. Chemical bonds in different environments will absorb varying intensities and at varying frequencies.

Table 1. Various glass compositions melted in mol percentage of oxides, density, optical band gap, type of vibrations and peak position in the FT-IR spectra of G1, G2, G3, G4 and G5 glass samples.

\begin{tabular}{|c|c|c|c|c|c|c|c|c|c|c|c|c|c|c|c|c|}
\hline \multirow{2}{*}{$\begin{array}{l}\text { Glass } \\
\text { code }\end{array}$} & \multicolumn{7}{|c|}{ Oxide (mol\%) } & \multirow{2}{*}{$\begin{array}{l}\text { Density } \\
\left(\mathrm{g} \mathrm{cc}^{-1}\right)\end{array}$} & \multirow{2}{*}{$\begin{array}{c}\text { Optical } \\
\text { band gap } \\
(\mathrm{eV})\end{array}$} & \multirow{2}{*}{$\begin{array}{c}\text { No. } \\
\text { of } \\
\text { peaks }\end{array}$} & \multirow{2}{*}{$\begin{array}{l}\text { Peak } \\
\text { position } \\
\left(\mathrm{cm}^{-1}\right)\end{array}$} & \multirow[b]{2}{*}{ Assignments } & \multicolumn{4}{|c|}{$\begin{array}{l}\text { Wavenumber of different } \\
\text { absorption peaks }\left(\mathrm{cm}^{-1}\right)\end{array}$} \\
\hline & $\mathrm{SiO}_{2}$ & $\mathrm{Al}_{2} \mathrm{O}_{3}$ & $\mathrm{MgO}$ & $\mathrm{K}_{2} \mathrm{CO}_{3}$ & $\mathrm{CaO}$ & $\mathrm{MgF}_{2}$ & $\mathrm{a}_{2} \mathrm{O}$ & & & & & & 1 & 2 & 3 & 4 \\
\hline G1 & 48 & 12 & 16 & 8 & 6 & 5 & 5 & 3.298 & 3.59 & 1 & 1631 & $\begin{array}{l}\mathrm{Si}-\mathrm{OH}, \mathrm{OH} \\
\text { (molecular water) }\end{array}$ & 1631 & 1384 & 759 & 645 \\
\hline G2 & 42 & 12 & 14 & 8 & 6 & 14 & 4 & 3.068 & 3.63 & 2 & 1384 & Hydrogen bonding & 1630 & 1383 & 761 & 638 \\
\hline G3 & 40 & 12 & 12 & 10 & 6 & 17 & 3 & 3.031 & 3.65 & 3 & $759-777$ & $\begin{array}{l}\text { Stretching vibration } \\
\text { of } \mathrm{SiO}_{4} \text { tetrahedron }\end{array}$ & 1630 & 1383 & 777 & 639 \\
\hline G4 & 38 & 12 & 10 & 12 & 6 & 20 & 2 & 2.277 & 3.65 & 4 & $670-704$ & $\begin{array}{l}\text { Bending vibrations } \\
\text { of } \mathrm{Si}-\mathrm{O}-\mathrm{Si} \text { and } \\
\mathrm{Si}-\mathrm{O}-\mathrm{Al} \text { linkages }\end{array}$ & 1631 & 1383 & 766 & 642 \\
\hline G5 & 36 & 12 & 8 & 14 & 6 & 24 & 0 & 2.104 & 3.63 & 5 & $645-615$ & $\begin{array}{l}\text { Asymmetric } \\
\text { stretching } \\
\text { vibrations of } \\
\mathrm{Al}-\mathrm{O}-\mathrm{Al} \text { bond } \\
\text { of octahedral } \\
\left(\mathrm{AlO}_{6}\right) \text { units }\end{array}$ & 1631 & 1384 & 759 & 644 \\
\hline
\end{tabular}




\subsection{UV-Vis spectroscopy}

UV-visible absorption spectroscopy is a very useful technique to characterize the optical and electronic properties of different materials such as thin films, filters, pigments and glasses. Measurement of the optical band gap of glass samples is carried out using the data within the wavelength range from 300-900 nm obtained by spectrophotometer. UV-Vis spectroscopy of the glass samples were carried out using UV-visible spectrophotometer model (Labtronic LT 2900). It measures the percentage of radiation in the different regions such as ultra-violet $(200-400 \mathrm{~nm})$, visible $(400-800 \mathrm{~nm})$ and near IR (800-1200 $\mathrm{nm}$ ) regions that is absorbed at each wavelength within ultra-violet, visible regions and near IR regions. The value of the direct band gap was calculated by using the given relation as:

$$
E=\frac{h c}{\lambda},
$$

where $h$ is the Plank's constant, $c$ the speed of light and $\lambda$ the wavelength.

\subsection{Drilling test}

Two small pieces have been cut from the bulk glass samples G1 and G2 with the help of diamond cutter of the size of $11 \times 9 \times 3 \mathrm{~mm}$. For the drilling test of the glass samples G1 and $\mathrm{G} 2$ are heat-treated at $1100^{\circ} \mathrm{C}$ for $3 \mathrm{~h}$ soaking time to convert into the glass ceramics.

\section{Results and discussion}

\subsection{XRD analysis}

The XRD patterns of all the glass samples are shown in figure 1 of glass compositions G1, G2, G3, G4 and G5, respectively. All the XRD patterns depict a broad diffuse scattering at different angles instead of sharp crystalline peaks, confirming a long range structural disorder characteristic of amorphous network. It is also observed that the XRD patterns of all the glass samples are almost similar and confirm the pure amorphous nature of the prepared glass samples.

\subsection{Density analysis of glass samples}

The density of the glasses (table 1) increased with addition of $\mathrm{La}_{2} \mathrm{O}_{3}$ due to its high density in comparison with other constituents of the glasses [18]. The values of density of the prepared glasses lie in the range from $2.104-3.061 \mathrm{~g} \mathrm{cc}^{-1}$. It is observed that the density of the glass samples G1, G2, G3, G4 and G5 are found to be increased with increasing doping concentration of lanthanum oxide which is due to the very high value of density of $\mathrm{La}_{2} \mathrm{O}_{3}\left(6.51 \mathrm{~g} \mathrm{cc}^{-1}\right)$ in comparison to other used oxides and it is also due to the decreasing content of $\mathrm{SiO}_{2}\left(2.65 \mathrm{~g} \mathrm{cc}^{-1}\right)$. A similar trend in molar

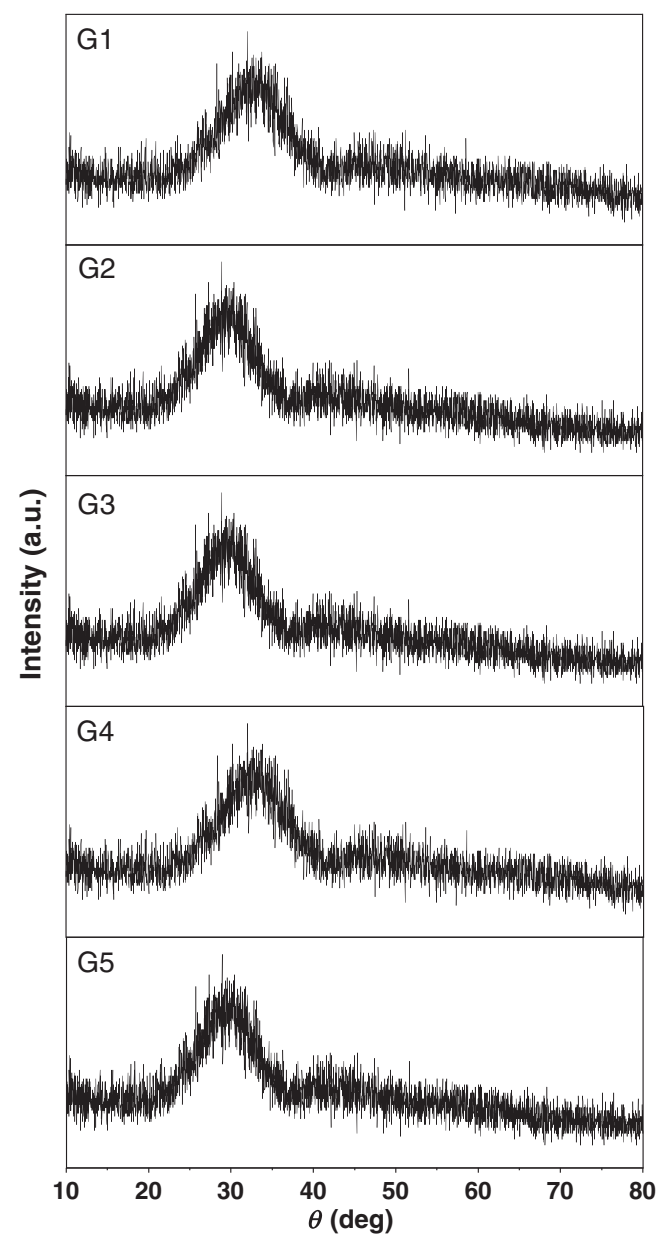

Figure 1. XRD patterns of G1, G2, G3, G4 and G5 glass samples.

volume (MV) was also observed with increasing $\mathrm{La}_{2} \mathrm{O}_{3}$ in the glasses. The MV of the glasses increases due to an increase in bond length or inter atomic spacing. In the present scenario, such an increase is due to the greater ionic radius of La $(0.1061 \mathrm{~nm})$ in comparison to the ionic radii of other glass constitutes [19] $\left(\mathrm{Si}^{4+}=0.026 \mathrm{~nm} ; \mathrm{Al}^{3+}=0.039 \mathrm{~nm}\right.$; $\left.\mathrm{Mg}^{2+}=0.058 \mathrm{~nm} ; \mathrm{Ca}^{2+}=0.100 \mathrm{~nm}\right)$. Therefore, the volume corresponding to the structural unit with its surrounding space, $V_{\mathrm{m}}$, is expected to increase by inserting a heavy metal oxide like $\mathrm{La}_{2} \mathrm{O}_{3}$. The density and increasing concentration of $\mathrm{La}_{2} \mathrm{O}_{3}$ are in good agreement with the results reported by Gautam et al [20].

\subsection{Fourier transform infrared spectroscopic study of glasses}

The Fourier transform infrared absorption spectra of annealed glass samples G1, G2, G3, G4 and G5 are shown in figures 2 and 3, respectively. FT-IR absorption peaks are very broad and sharp in nature towards the lower as well as higher wavelength side in the patterns of the glass samples. The observed absorption peaks have been numbered as $1,2, \ldots, 4$ starting from higher wavenumber side to lower 


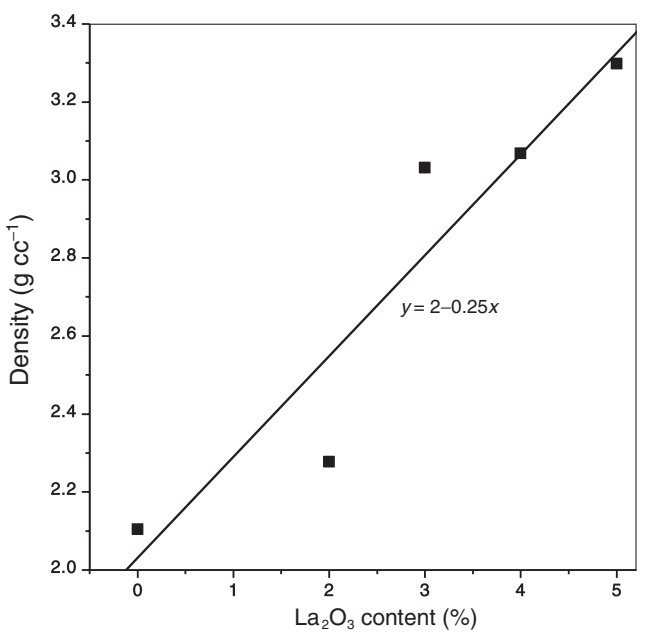

Figure 2. Variation of density $v s$. $\mathrm{La}_{2} \mathrm{O}_{3}$ content.

wavenumber side. The vibration types and IR absorption peaks of glasses G1, G2, G3, G4 and G5 are summarized in table 1. All annealed glasses showed four main absorption bands in the wavenumber region from 638 to $1631 \mathrm{~cm}^{-1}$ which are related to different types of the vibrations. Two broad bands were observed with lower wavenumber side at 759 and $644 \mathrm{~cm}^{-1}$, indicate the general disorder in the silicate network, mainly due to the wide distribution of $Q^{n}$ units (polymerization in the glass structure, where $n$ denotes the number of bridging oxygens) occurring in the glasses [21]. In the IR spectra of these glasses, the band at $759 \mathrm{~cm}^{-1}$ has been also attributed to the vibrations of $\mathrm{Si}-\mathrm{O}-\mathrm{Si}$ groups with major movement of the silicon ions [22]. Aluminium containing crystalline silicates and aluminates show a band at $760 \mathrm{~cm}^{-1}$ corresponding to the stretching vibrations of the A1-O bond with aluminium in four-fold coordination [23]. The peak no. 4 at $645 \mathrm{~cm}^{-1}$ attributed to asymmetric stretching vibrations of $\mathrm{Al}-\mathrm{O}-\mathrm{Al}$ bond of octahedral $\left[\mathrm{AlO}_{6}\right]$ units of $\mathrm{Al}_{2} \mathrm{O}_{3}$ molecules [24,25]. The most intense broad band towards the low wavenumber side, $1200 \mathrm{~cm}^{-1}$, represents the distribution of stretching vibrations in the $\mathrm{SiO}_{4}$ tetrahedron with different numbers of bridging oxygen atoms with the centre of gravity fixed at $\sim 697 \mathrm{~cm}^{-1}$ (centre of the peaks 3 and 4) while the band in the $500-700 \mathrm{~cm}^{-1}$ region corresponds to bending vibrations of $\mathrm{Si}-\mathrm{O}-\mathrm{Si}$ and $\mathrm{Si}-\mathrm{O}-\mathrm{Al}$ linkages [26]. In case of aluminium coordination in the glass structure, the presence of an absorbance band of medium towards strong intensity in the $650-750 \mathrm{~cm}^{-1}$ region with the centre of gravity at $\sim 697 \mathrm{~cm}^{-1}$ is a typical feature for peralkaline glasses, and implies the tetrahedral coordination of $\mathrm{Al}$ [27]. Background noises were observed in all FT-IR spectra of the glass samples in the region from 3200 to $4000 \mathrm{~cm}^{-1}$. It is also observed from the FT-IR spectra of the all glass samples that lower wavenumber side was more effective rather than high wavenumber side. Very intense and broad bands are present in the FT-IR spectra which indicate the good signature of the formation of glassy network.

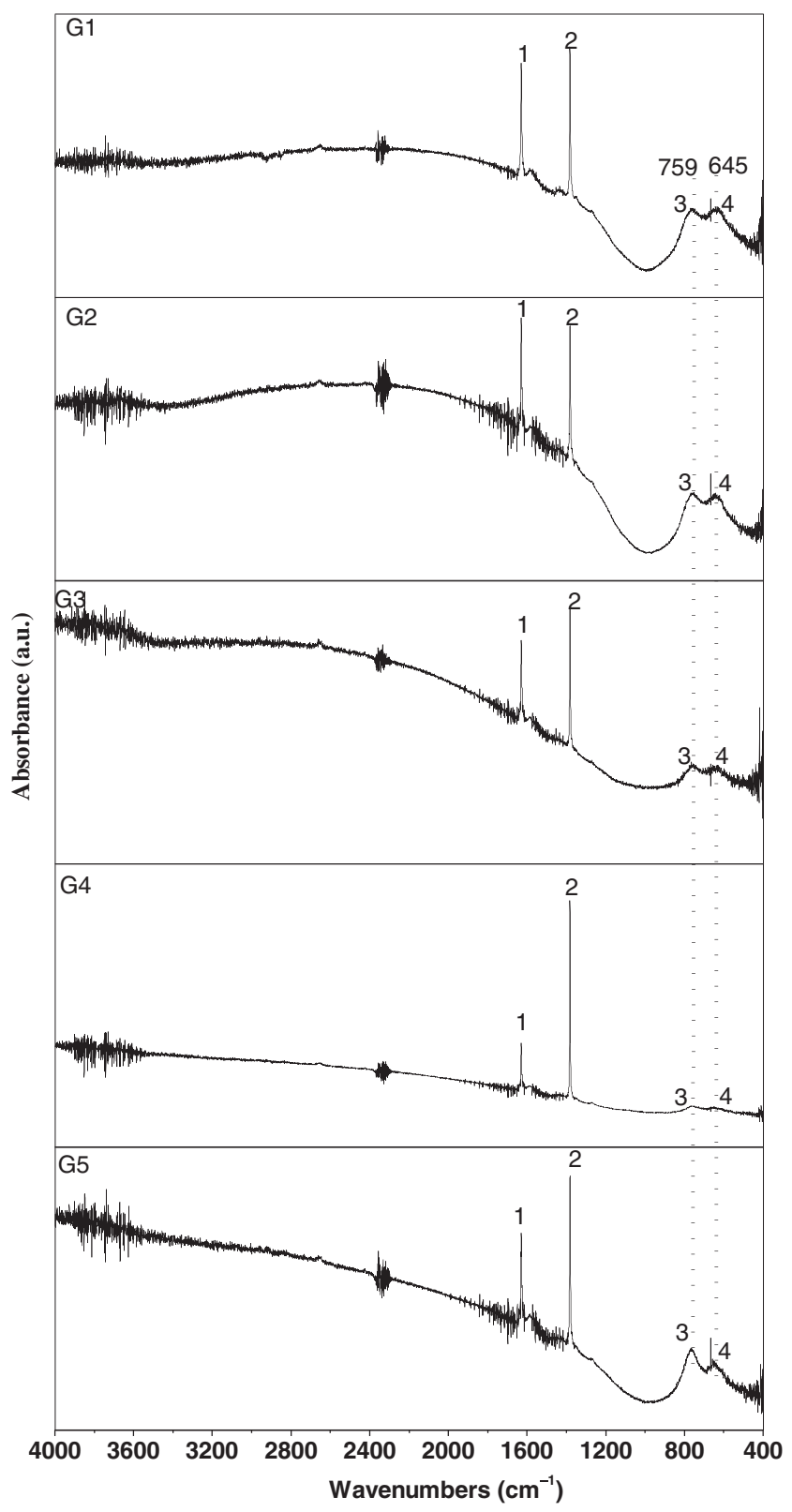

Figure 3. FT-IR spectra of different glass samples: G1, G2, G3, G4 and G5.

\section{$3.4 \quad U V-V i s$ spectroscopy}

UV-visible absorption spectra of various glass samples G1, G2, G3, G4 and G5 are shown in figure 4. There is only a sharp increase in absorption at energies close to the band gap that manifests itself as an absorption edge in the UVvisible absorption spectra of all the glass samples which guarantees the amorphous nature of glass samples. Generally, the absorption edge of the glass samples is determined by the strength of the oxygen bonding in the glass network. The changes in oxygen bonding in the glass network will change the characteristics of the absorption edge. As the material absorbs a photon of incident light, an electron is excited to a higher energy level [28]. Only a single transition 
occurs in the wavelength region from 310 to $376 \mathrm{~nm}$ which is represented by two dotted parallel lines in all UV-Vis spectra [29]. The calculated values of optical band using equation (2) are listed in table 1. It is found that absorption edge intensity is increasing with decreasing content of the $\mathrm{La}_{2} \mathrm{O}_{3}$. It is observed from table 1 that the values of optical band gap initially increases with decreasing the amount of $\mathrm{SiO}_{2}, \mathrm{MgO}$ and $\mathrm{La}_{2} \mathrm{O}_{3}$, respectively. This is due to the lower value of the band gap for lanthanum oxide $(4.3 \mathrm{eV})$ in comparison with the above oxides. This shows the composition dependence of optical band gap of the synthesized glass samples.

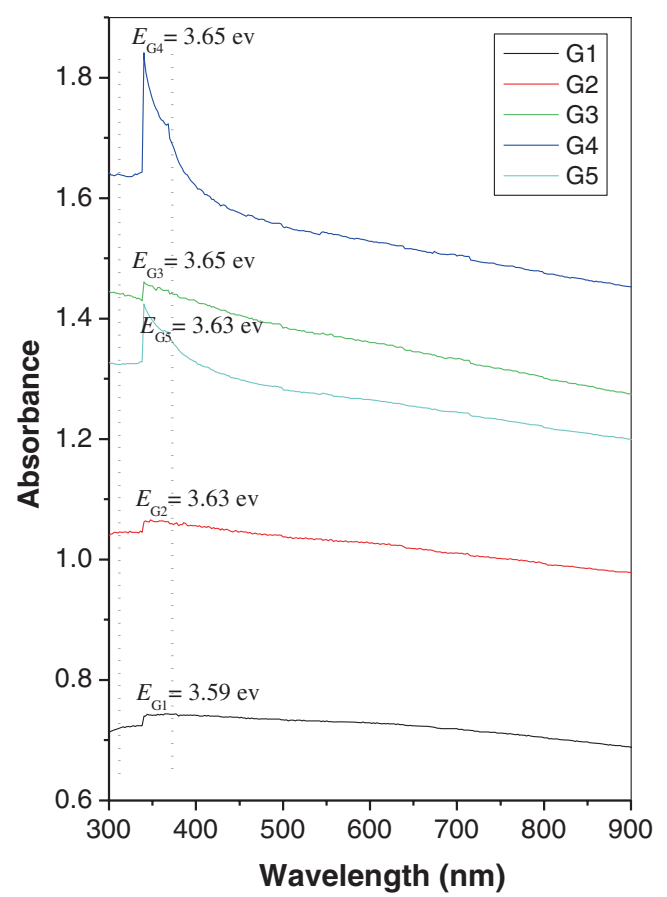

Figure 4. UV-Vis spectra of G1, G2, G3, G4 and G5 glass samples.

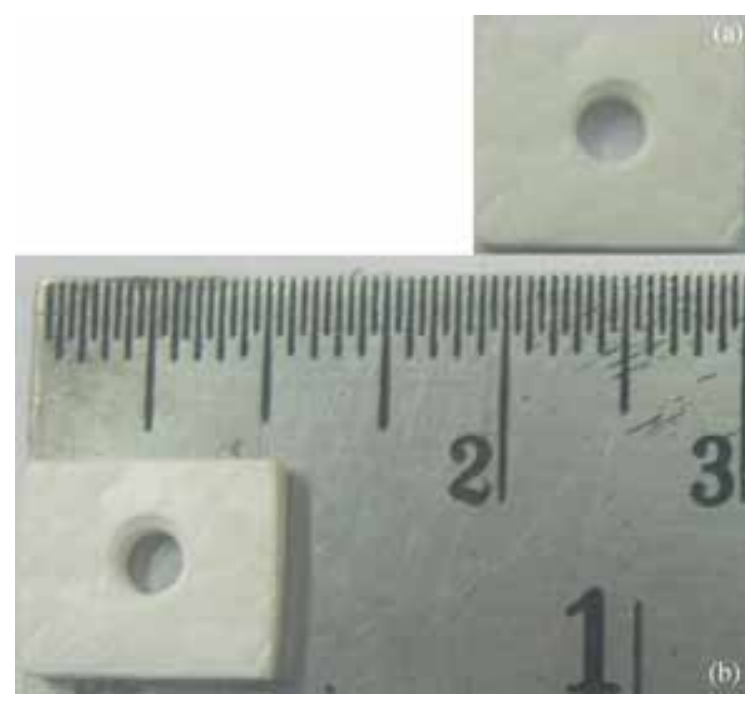

Figure 5. Photograph of drilling test for (a) GC1 and (b) GC2 specimens heated at $1100^{\circ} \mathrm{C}$ for $3 \mathrm{~h}$.

\subsection{Mechanical behaviour}

The machined samples are shown in figure 5a and b. The rectangular shaped sample was cut using a diamond cutter before the machinability test. The glass ceramic samples GC1 and GC2, which are derived from their parent glass samples G1 and G2 showed excellent machinability, and a $3 \mathrm{~mm}$ thick hole was drilled successfully and completely. According to the results, the appropriate machining performance was obtained by using conventional heat treatment procedure without cracking the samples and confirm the very good machinability [30,31].

\section{Conclusion}

Bulk transparent glasses were prepared successfully in the glass $\mathrm{SiO}_{2}-\mathrm{Al}_{2} \mathrm{O}_{3}-\mathrm{MgO}-\mathrm{K}_{2} \mathrm{CO}_{3}-\mathrm{CaO}-\mathrm{MgF}_{2}-\mathrm{La}_{2} \mathrm{O}_{3}$ system. XRD analysis confirms the amorphous nature of the glasses. The density and the molar volume of the glasses increased as the $\mathrm{La}_{2} \mathrm{O}_{3}$ content increased. The increase in the density of the glass is due to the heavier lanthanum atomic weight compared with the other elements in the glass system. The increase in the molar volume of the glass is due to the increase in bond length or inter atomic spacing. FT-IR spectra show the formation of broad bands towards lower wavenumber side indicating these glasses are more effective and informative with respect to the lower wavenumber side. Stretching vibrations occur in the wavenumber range 850$990 \mathrm{~cm}^{-1}$ due to $\mathrm{SiO}_{4}$ tetrahedron with different numbers of bridging oxygen atoms, while the band in the region 500$700 \mathrm{~cm}^{-1}$ corresponds to bending vibrations of $\mathrm{Si}-\mathrm{O}-\mathrm{Si}$ and $\mathrm{Si}-\mathrm{O}-\mathrm{Al}$ linkages. Optical band gap value lies in the range from 3.59 to $3.65 \mathrm{eV}$. Significant change was not observed in the value of optical band gap which shows the chemical stability of the prepared glasses. The produced glass ceramics exhibited excellent performance in machinability tests. These tests were carried out on both GC1 and GC2 samples without cracking or deformation.

\section{Acknowledgements}

Dr C R Gautam is very grateful to UGC, New Delhi, India, for providing the financial support under UGC research award no. F. 30-33/2011 (S.A.). Prof Rakesh Kumar Dwivedi, Department of Physics and Materials Science Engineering, Jaypee Institute of Information Technology, Noida, India, is also acknowledged for extending the FT-IR facility.

\section{References}

[1] Merzbacher C I and White W B 1991 J. Non-Cryst. Sol. 13018

[2] Beal G H, Montierth M R and Smith G P 1972 Tonind. Ztg. Keram. 95351

[3] Grossman D G 1972 J. Am. Ceram. Soc. 55446 
[4] Yu L, Xiao H and Cheng Y 2008 Ceram. Int. 3463

[5] Saucedo E M, Perera Y M and Robles D 2012 Ceram. Int. 383161

[6] Mallik A, Basumajumdar A, Kundu P and Maiti P K 2013 Ceram. Int. 392551

[7] Hill R 1996 J. Mater. Sci. Lett. 151122

[8] Elgayar I, Aliev A E, Boccaccini A R and Hill R G 2005 J. Non-Cryst. Solids 351173

[9] Gautam C R, Kumar D and Parkash O 2010 Bull. Mater. Sci. 33145

[10] Gautam C R, Kumar D, Singh P and Parkash O 2012 ISRN Spect. 20121

[11] Gautam C R, Singh P, Kumar D and Parkash O 2013 Bull. Mater. Sci. 36461

[12] Boch P and Niepce J C (ed.) 2007 Ceramic materials processes in Properties and Applications (London: ISTE)

[13] Nassar A M, Hamzawy E M A, Hafez F M, El Dera S S and Russel C 2012 Ceram. Int. 381921

[14] Tulyaganov D U, Agathopoulos S, Fernandes H R, Ventura J M and Ferreira J M F 2004 J. Eur. Ceram. Soc. 243521

[15] Taruta S, Ichinose T, Yamaguchi T and Kitajima K 2006 J. Non-Cryst. Solids 3525556

[16] Hong Li, De-Qiang Y, Chang-Ren Z and Jun-Guo R 2006 J. Mater. Sci.: Mater. Med. 171133

[17] Gautam C R, Madheshiya A and Mazumder R 2014 J. Adv. Ceram. 3194
[18] Gautam C R and Yadav A K 2013 Opt. Photo. J. 31

[19] Reddy A A, Tulyaganov D U, Kapoor S, Goel A, Pascual M J, Khartona V V and Ferreira J M F 2012 RSC Advances 210955

[20] Gautam C R, Yadav A K, Mishra V K and Vikram K 2012 Open J. Inor. Non-Meta. Mater. 247

[21] Tarte P 1967 Spectrochim. Acta 232127

[22] Jellyman P E and Procter J P 1955 J. Soc. Glass Tech. 39173

[23] Kolesova V A 1960 The structure of glass (Translated from Russian) (New York: Consultant Bureau) vol 2, p 177

[24] Motke S G, Yawale S P and Yawale S S 2002 Bull. Mater. Sci. 2575

[25] Burdick V L and Day D E 1967 J. Am. Ceram. Soc. 5097

[26] Sharma S K, Yoder Jr H S and Matson D W 1988 Geochim. Cosmochim. Acta 521961

[27] Pascual M J, Duran A and Prado M O 2005 Phys. Chem. Glass 46512

[28] Zaid M H M, Matori K A, Aziz S H A, Zakaria A and Ghazali M S M 2012 Int. J. Mol. Sci. 137550

[29] Ghasemzadeh M, Nemati A, Hamnabard Z, Baghshahi S and Nozad G A 2012 Synt. React. Inorg., Metal-Org. Nano-Metal. Chem. 42958

[30] Ghasemzadeh M and Nemati A 2012 Bull. Mater. Sci. 35853

[31] Ercenk E and Yilmaz S 2015 J. Ceram. Proc. Res. 16169 